\title{
The Analysis of an Ancestral Caddo Ceramic Vessel from 41NA16 in Nacogdoches County in East Texas
}

Timothy K. Perttula

Follow this and additional works at: https://scholarworks.sfasu.edu/ita

Part of the American Material Culture Commons, Archaeological Anthropology Commons, Environmental Studies Commons, Other American Studies Commons, Other Arts and Humanities Commons, Other History of Art, Architecture, and Archaeology Commons, and the United States History Commons

Tell us how this article helped you.

This Article is brought to you for free and open access by the Center for Regional Heritage Research at SFA ScholarWorks. It has been accepted for inclusion in Index of Texas Archaeology: Open Access Gray Literature from the Lone Star State by an authorized editor of SFA ScholarWorks. For more information, please contact cdsscholarworks@sfasu.edu. 


\section{The Analysis of an Ancestral Caddo Ceramic Vessel from 41NA16 in Nacogdoches County in East Texas}

\section{Creative Commons License}

\section{(c) (1) \&}

This work is licensed under a Creative Commons Attribution-NonCommercial 4.0 International License 


\title{
The Analysis of an Ancestral Caddo Ceramic Vessel from 41 NA16 in Nacogdoches County in East Texas
}

\author{
Timothy K. Perttula
}

Included in the ancestral Caddo ceramic vessels in the Texas Archeological Research Laboratory (TARL) whole vessel collection is one vessel from a reported site in the Attoyac Bayou basin: 41NA16 (H. G. Moore) in Nacogdoches County in East Texas (Figure 1). The Attoyac Bayou is a major southward-flowing tributary to the Angelina River. The vessel is fully documented in this article.

\section{Natural Regions of Texas}

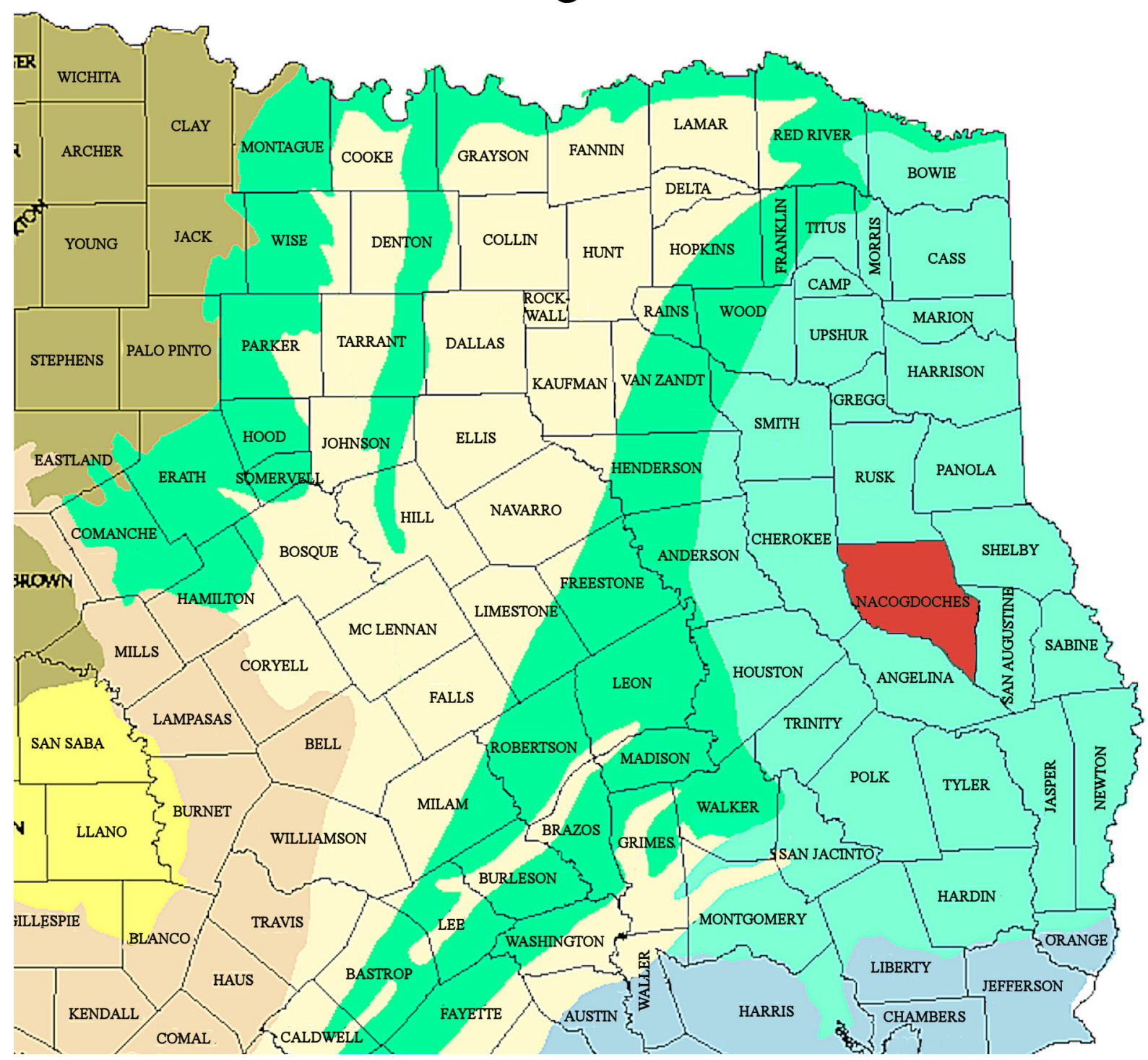

Figure 1. Nacogdoches County in East Texas. 


\section{H. G. Moore site (41NA16)}

The one ceramic vessel from the H. G. Moore site is in the TARL whole vessel collection. It was found in an ancestral Caddo burial feature near Attoyac Bayou, and ca. 20 miles east of the city of Nacogdoches. Along with the ceramic vessel, the burial feature had two associated elbow pipes decorated wither with appliqued nodes at the base of the bowl or with two incised lines at the base of the bowl.

SITE NAME OR SITE NUMBER: H. G. Moore

VESSEL NO.: 1 (cast)

VESSEL FORM: Jar with two appliqued strap handles (16 $7 \mathrm{~mm}$ in length and width) and a fourlegged pedestal base (Figure 2). The pedestal base is $32 \mathrm{~mm}$ in height, and the pedestals are $9.2 \mathrm{~mm}$ in width. the square pedestal base is $51 \mathrm{~mm}$ in length, and its four sections are $11.4 \mathrm{~mm}$ in width.

NON-PLASTICS AND PASTE: N/A

RIM AND LIP FORM: Everted rim and rounded, exterior folded, lip

CORE COLOR: N/A

INTERIOR SURFACE COLOR: N/A

EXTERIOR SURFACE COLOR: N/A

WALL THICKNESS (IN MM): rim, $4.3 \mathrm{~mm}$

INTERIOR SURFACE TREATMENT: N/A

EXTERIOR SURFACE TREATMENT: N/A

HEIGHT (IN CM): 12.1

ORIFICE DIAMETER (IN CM): 7.9

DIAMETER AT BOTTOM OF RIM OR NECK (IN CM): 7.7

BASE DIAMETER (IN CM) AND SHAPE OF BASE:

$5.1 \mathrm{~cm}$, square and flat

ESTIMATED VOLUME (IN LITERS): 0.6

\section{DECORATION (INCLUDING MOTIF AND}

ELEMENTS WHEN APPARENT): The vessel rim panel has eight sets of vertical engraved lines with upper and lower hatched pendant triangles (Figure 2), comparable to Poynor Engraved, var. Blackburn vessels (Perttula 2011:Figure 6-64b). Where this vessel differs from var. Blackburn is in the four sets of concentric circle elements on the vessel body; inside the innermost circle in each set is a single excised dot (Figure 2).

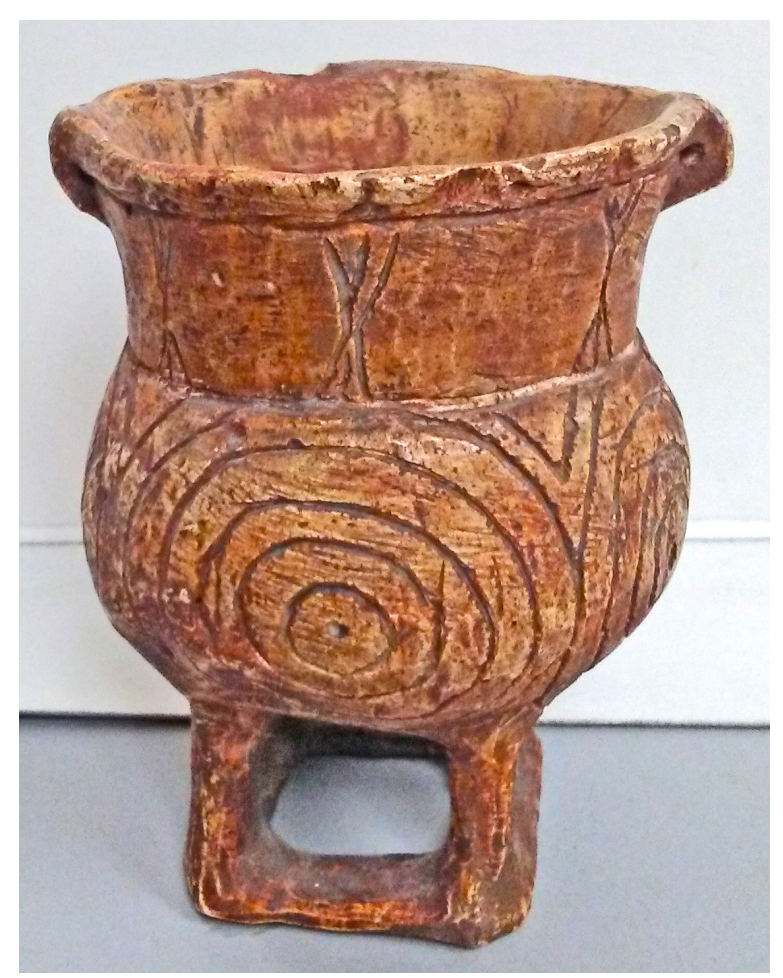

Figure 2. Poynor Engraved, var. unspecified jar (No. 1) from the H. G. Moore site. 
PIGMENT USE AND LOCATION ON VESSEL: none

TYPE AND VARIETY (IF KNOWN): Poynor Engraved, var. unspecified

\section{Summary and Conclusions}

One ancestral Caddo ceramic vessel of Late Caddo period age (ca. post-A.D. 1450) has been documented from the H. G. Moore (41NA16) site along Attoyac Bayou in the Angelina River basin in Nacogdoches County, Texas. The unique vessel from the H. G. Moore site is a Poynor Engraved, var. unspecified pedestalled jar with appliqued handles. Two decorated elbow pipes were also found in the burial feature at the H. G. Moore site.

\section{Acknowledgments}

Thanks to the staff at the Texas Archeological Research Laboratory for access to their whole vessel collections. Lance Trask prepared Figure 1 in the article.

\section{References Cited}

Perttula, T. K.

2011 The Ceramic Artifacts from the Lang Pasture Site (41AN38) and the Place of the Site within an Upper Neches River Basin Caddo Ceramic Tradition. In Archeological Investigations at the Lang Pasture Site (41AN38) in the Upper Neches River Basin of East Texas, assembled and edited by T. K. Perttula, D. B. Kelley, and R. A. Ricklis, pp. 145-320. Archeological Studies Program Report No. 129, Texas Department of Transportation, Environmental Affairs Division, Austin. 